\title{
Petro-physical Analysis of Well Logs for Reservoir Evaluation: A Case Study of Well 1 and 2 of the 'Ictorian' Field in the Niger Delta Basin
}

\author{
*MAJU-OYOVWIKOWHE, GE; NJOKU, VK
}

Department of Geology, Faculty of Physical Sciences, University of Benin, Benin City. Nigeria.

*Corresponding Author Email: efetobore.maju@uniben.edu

\begin{abstract}
This study presents the log analysis results of a suite of conventional wireline logs including gamma ray, density, neutron, and resistivity from two wells in 'Ictorian' Field located in the Niger delta with the aim of evaluating hydrocarbon prospect of the field. Results obtained showed presence of hydrocarbon in eleven (11) reservoirs from well 1, and four (4) reservoirs from well 2. Well 1 and 2 both had hydrocarbon reservoir bearing gas. Well 1 had Gas Water contact at $2497 \mathrm{~m}$ and $2964 \mathrm{~m}$, while well 2 had Gas water Contacts at $1739 \mathrm{~m}$ and $2510 \mathrm{~m}$. Effective porosities had values ranging from $26-16 \%$ in well 1 . In well 2 , effective porosities had values ranging from $22-17 \%$. The values obtained show that the analysed reservoirs have good permeability. The calculated values indicate that porosity, permeability values from the hydrocarbon bearing reservoirs are good enough for commercial accumulation in the Niger Delta. It is recommended that for field optimization mud logging data and core data analysis should be integrated as part of the evaluation exercise.
\end{abstract}

\section{DOI: https://dx.doi.org/10.4314/jasem.v23i6.1}

Copyright: Copyright $\mathbb{C} 2019$ Maju-Oyovwikowhe and Njoku. This is an open access article distributed under the Creative Commons Attribution License (CCL), which permits unrestricted use, distribution, and reproduction in any medium, provided the original work is properly cited.

Dates: Received: 07 May 2019; Revised: 11 June 2019; Accepted 24 June 2019

Keywords: Reservoir, petrophysical properties, reservoir quality, wireline logs.

Petroleum in the Niger Delta is produced from sandstones and unconsolidated sands predominantly in the Agbada Formation. Recognized known reservoir rocks are of Eocene to Pliocene in age, and are often stacked, ranging in thickness from less than 15 meters to $10 \%$ having greater than 45 meters thickness. (Evam et al.1978). Based on reservoir geometry and quality, the lateral variation in reservoirs thickness is strongly controlled by growth faults; with the reservoirs thickening towards the fault within the down-thrown block (Weber and Daukoru, 1975). A reservoir is a subsurface rock that has effective porosity and permeability which usually contains commercially exploitable quantity of hydrocarbon. Petrophysical logs interpretations used for the characterization of reservoir sands are very useful and important tools for selecting, planning and implementing operationally sound supplementary recovery schemes (Ekine and Iyabe, 2009). Furthermore, the pores and fractures have to be interconnected if the hydrocarbons will eventually be produced as such hydrocarbons are needed to flow towards production wells. Porosity and permeability are thus key reservoir parameters in this regard and as such parts of the Niger Delta opportunities have been captured at the shallow, intermediate and deep levels (Olowokere, 2009b).The search or economic accumulations of oil and gas starts with the recognition of likely geological provinces, progresses to seismic surveying, and the drilling of one or more wild-cat wells. If one is lucky, these wells may encounter oil, and if that is the case, measurements made down the hole with wireline tools are used to assess whether sufficient oil is present, and whether it can be produced. Clearly, the evaluation of sub-surface formations requires the combined efforts of geologists, Petrophysicists, drilling engineers and even geophysicists. However, it is the geologist and Petrophysicist that has the most influence. The geologist is interested in the lithology, stratigraphy and depositional environment of the subsurface strata penetrated by the drilling bit. The exploration geologist uses wireline tool responses in a number of wells to create a large scale image of the sub-surface geology by correlating wireline responses that are characteristic of a given formation or horizon between formations. This picture is very useful when carrying out initial reservoir modelling and in the decision where to drill new wells. Later the production geologist carries out much the same process with much more well information, and adds any extra information that has been gathered to produce a detailed geological model of the reservoir and related sub-surface formations. This model will be the basis of reservoir modelling, and all major reservoir management decisions from primary drainage through to enhanced oil recovery and shut-down. The Petrophysicist'sjob is to use all available information to analyse the physical and chemical properties of the rocks in the sub-surface,

*Corresponding Author Email: efetobore.maju@uniben.edu 
and their component minerals, with particular emphasis given to the amount and distribution of those fluid minerals that we know of as water, oil, and gas. The petrophysicist will use extensively wireline log data and data from experiments done on cores extracted from the well, and will occasionally use other sources of information such as engineering and production logs, as well as mud logging data. Initially, it is the aim of the Petrophysicist to differentiate between oil, gas and water bearing formations, estimate the porosity of the formations and the approximate amount of hydrocarbons present in each formation. Ultimately, the Petrophysicist also uses laboratory data to estimate how easy it will be to extract the hydrocarbons in place, and to design reservoir management strategies to optimize long term oil recovery. There is a large database of information available to both the geologist and the Petrophysicist, and as time passes the amount and variety of information increases. The formation evaluation and reservoir characterization of some parts of Niger Delta revealed the two major lithological units in the area to be sand and shale (Abe and Olowokere, 2013; Ologe, 2016); a good reservoir is one that is commercially productive if it produces enough oil or gas to pay back its investors for the cost of drilling and leaves a profit. This study is to evaluate the reservoir quality and production potential of the 'Ictorian' Field in the Niger Delta Basin. These are essential for both economic evaluations of the reservoir and production planning of an optimum recovery method.

\section{MATERIALS AND METHODS}

Description of study area: The study wells (well 1 and 2) of the "Ictorian" field are located within the oil province of the Niger delta basin, South South Nigeria.

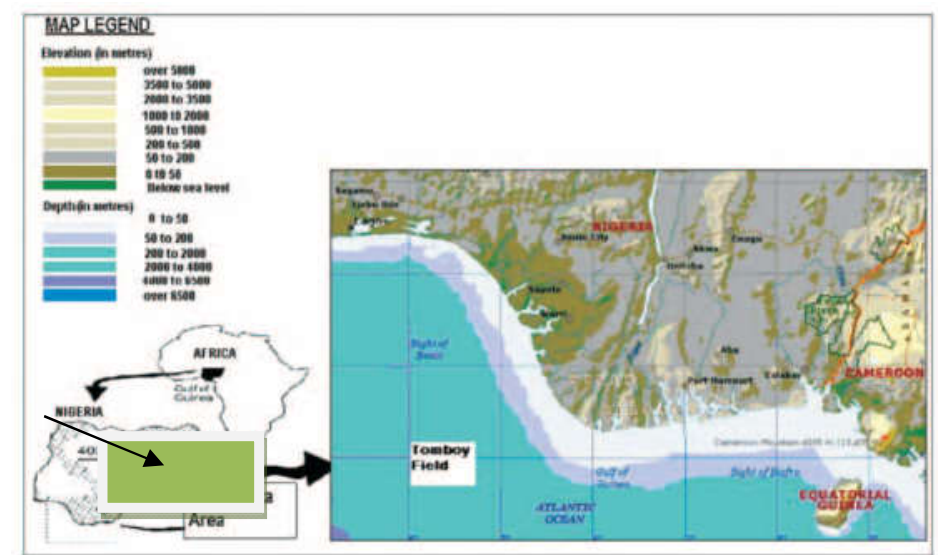

Fig 1: Location map of the study area (Modified from Owoyemi, 2004 and Microsoft Encarta, 2006)

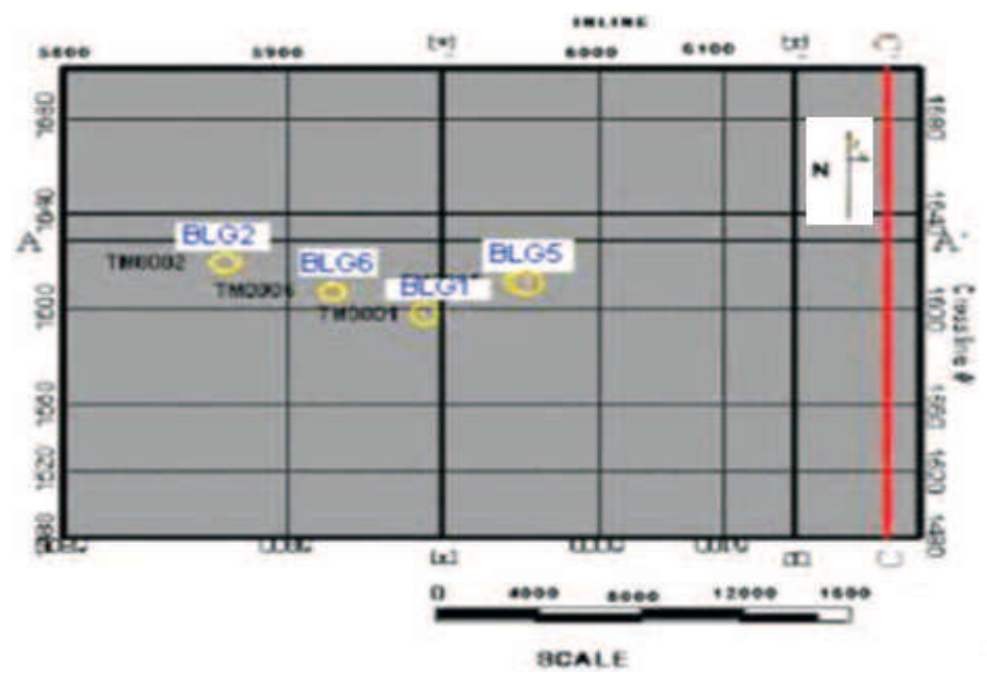

Fig. 2: Field base map of study area 
Estimation of Petro-physical Parameters: The materials used for this study are from National Petroleum Development Company (NNPC), which include geophysical wire-line log data (gamma-ray $\log$, neutron-density $\log$ and resistivity $\log$ ). The analysis of the geophysical wire-line logs was done manually. Lithology was interpreted using the combination of the gamma ray and spontaneous potential $\operatorname{logs}$ of each well, followed by the lithostratigraphic correlation of the wire-line logs.

Formation Evaluation of studied wells: In the present study, the hydrocarbon bearing reservoirs was analysed from the resistivity log. Generally water bearing zones have very low resistivity since they are conductive and the hydrocarbon bearing zone had relatively high resistivity because they are nonconductive. The hydrocarbon was differentiated into oil and gas using the neutron-density combination log. The average porosity was estimated from the neutron density cross plot, the effective porosity was further deduced by introducing the shale volume percentage. Effective porosities were estimated and these effective porosities determine the permeability of the reservoirs. Water saturation and hydrocarbon saturation was estimated from the formation resistivity values gotten from the resistivity log.

Table 1. Qualitative evaluation of porosities.

\begin{tabular}{ll}
\hline Percentage Porosity & Qualitative Evaluation \\
\hline $\mathbf{0 - 5}$ & Negligible \\
$\mathbf{5 - 1 0}$ & Poor \\
$\mathbf{1 5 - 2 0}$ & Good \\
Over 20-25 & Very good \\
Over 30 & Excellent \\
\hline
\end{tabular}

Evaluation techniques: The evaluation sequence used for the present study is given below. (1) Distinguish between reservoir and non-reservoir rock (Reservoir rock contains a reasonably high connected porosity.) (2) For the reservoir intervals only, distinguish between hydrocarbons and water filling the pores, hence calculate water saturation in reservoir rocks (Hydrocarbons are electrical insulators, while water conducts.) (3) For the hydrocarbon fraction, distinguish between oil and gas, hence calculate gas and oil saturations in reservoir rocks (Gas has a much lower density than oil.)

Reservoir identification: Lithology identification was done with the gamma ray log. A review of the Niger delta basin indicated sands as the major reservoir rocks. Within the gamma ray log strip, the beds with high GR readings were taken as shale while those with low GR readings were taken as sands. The GR level of the thickest shale bed is read and this reading is assumed to represent $100 \%$ shale and a straight line drawn through this point is the shale line. Similarly a sand line was also drawn representing the average GR reading for a thick sand bed (100\% clean sand) which is equal to the sand with the lowest gamma ray reading. A vertical line through the midpoint between the sand and shale line is constructed and is called the cut-off line. On the basis of this cut-off line all intervals where the GR $\log$ is on the left are assumed to be sandstones and any interval on the left is assumed to be shale.

During the evaluation of the logs, for well 1

- $\quad$ Sand line value was 22 API.

- $\quad$ Shale line value was 90 API.

For well 2

- $\quad$ Sand line value was 25 API.

- $\quad$ Shale line value was 100 API

Reservoir thickness estimation: The gamma ray log was also used in estimating the thickness of reservoirs. This was done with the aid of appropriate depth interval measurements (in meters) on the gamma ray $\log$ strip. The reservoirs were divided into zones and the thickness of the reservoir zone used in this calculation is the net sand. The net sand is the thickness of clean, permeable, hydrocarboncontaining sand in the reservoir zone. This is the thickness of sand in the reservoir zone irrespective of whether it is clean, its permeability or its fluid saturation. The net to gross ratio (thickness of net sand divided by the thickness of gross sand) is often used to represent the quality of a reservoir zone.

Shale volume calculation: The maximum and minimum of gamma ray were used to compute shale volume. This was done using the gamma ray log to get the sand and shale readings in API then estimate the volume of shale in the reservoir as follows:

$$
\text { Vsh }=\frac{\text { GRlog }- \text { GRmin }}{\text { GRmax }- \text { GRmin }} \times 100
$$

Porosity determination: The relative amount of pore space to the bulk volume is denoted by the porosity $\emptyset$, where the porosity is the fraction of the bulk volume occupied by pore volume, and is expressed as a fraction or as a percentage;

$$
\emptyset=\text { Vpore } / \text { Vbulk }
$$

The porosity values were obtained using the both density and neutron log for accuracy and consistency and of porosities. This was done by plotting the bulk density $(\rho b)$ and the neutron porosity (p.u) on the Xplot and determining the Lithology and porosity estimate on each lithologic line. The X-plot is very useful in correcting for porosities in gas bearing reservoirs. However, the fractional form is used in all calculations. The majority of rock volume is occupied 
by the solid rock matrix, and the remainder is made up of the pore space between the minerals.

Hydrocarbon detection: This is established from the deep resistivity logs for a particular reservoir interval. This is in line with the principle that water bearing reservoirs have relatively low deep resistivity because water is highly conductive and hydrocarbon bearing reservoirs have relatively high deep resistivity because they are non-conductive. After detecting the presence of hydrocarbon a further distinction on the type of hydrocarbon present (oil or gas) is determined with the aid of the neutron density log. Gas has a signature balloon effect (large separation between neutron and density $\log$ ) while oil a no balloon effect (a smaller separation)

\begin{tabular}{|c|c|}
\hline Petro-physical properties & Formula applied \\
\hline Porosity (average) & $\begin{array}{l}\bar{\emptyset}=\frac{\sum ø i . h i}{\sum h i} \text {; Where } \varnothing i \text { is the individual porosities for all the blocks of the reservoir zone and hi } \\
\text { represents the thickness of each block. }\end{array}$ \\
\hline Effective porosity & $\bar{\emptyset} \mathrm{e}=\varnothing(1-V s h)$ \\
\hline Resistivity of water & $\begin{array}{l}R w=\frac{R o}{\phi^{-m}} \text {; Where Ro is the resistivity of the water bearing zone (from the log) and } \mathrm{m} \text { is the } \\
\text { cementation factor }\end{array}$ \\
\hline $\begin{array}{l}\text { Formation resistivity } \\
\text { factor }\end{array}$ & $\begin{array}{l}F=\frac{a}{\phi-m} ; \mathrm{a}=\text { turtousity factor }(\text { From archies equation } \mathrm{a}=0.81) \text { and } \mathrm{m}=\text { cementation factor which } \\
\text { is taken as }=2\end{array}$ \\
\hline Water saturation & $S w=\left(\frac{a R w}{\emptyset^{m} R}\right)^{\frac{1}{n}} ;$ Where $\mathrm{Rt}=$ the formation resistivity; $\mathrm{n}=$ saturation exponent \\
\hline Hydrocarbon saturation & $S h c=(1-S w)$ \\
\hline Bulk volume water & $B v w=S w \times \bar{\emptyset}$ \\
\hline Volume of shale & $\begin{array}{l}\text { Vsh }=\frac{G R l o g}{G R \operatorname{GRmin}} \times 100 \text {; Where,GRlog }=\text { GR of formation measured from } \log \text {; GRmin = } \\
\text { Least GR in zone of interest, GRmax= Maximum GR reading in formation of interest, Vsh= } \\
\text { Volume of Shale }\end{array}$ \\
\hline
\end{tabular}

Hydrocarbon saturation: In general the porosity is completely occupied by either water or hydrocarbon, where the saturation of the water is $S w$, and that of the hydrocarbon is $S h$, and $S w+S h=1$. In most reservoirs the hydrocarbon has replaced all the water that it is possible to replace, and under these conditions the water saturation is termed the irreducible water saturation $S w$. Now we can write the hydrocarbon saturation as $S h=(1-S w)$.

Petro-physical characteristics of the reservoirs: The petro-physical parameters calculated and used for the hydrocarbon analysis include:

Table 3 and 4 presents the results of the log analysis.

Table 3. Results of average petro-physical parameters of the eleven (11) reservoirs of well 1

\begin{tabular}{|c|c|c|c|c|c|c|c|c|c|c|c|c|c|c|c|c|c|c|}
\hline 章 & 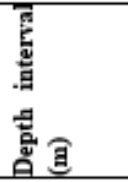 & 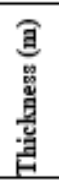 & 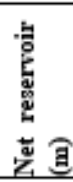 & 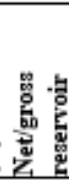 & 㴔 & 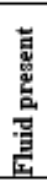 & 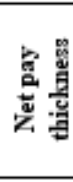 & 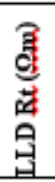 & 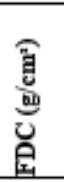 & $\begin{array}{l}3 \\
\text { 是 } \\
\text { 是 }\end{array}$ & 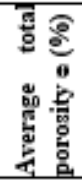 & $\stackrel{8}{\stackrel{5}{2}}$ & 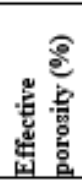 & 幽 & $\frac{8}{8}$ & $\frac{\stackrel{8}{8}}{\frac{y}{\sqrt{3}}}$ & 山 & $\frac{1}{6}$ \\
\hline 1 & $2405-2435$ & 30 & 22 & 0.73 & sand & gas & 22 & 200 & 1.90 & 7 & 32 & 18 & 26.24 & 0.13 & 8 & 92 & 7.9 & 2.56 \\
\hline 2 & $\begin{array}{l}2438- \\
2452.5\end{array}$ & 14.5 & 9 & 0.62 & sand & gas & 9 & 43 & 2.00 & 16 & 32.2 & 41 & 19 & 0.13 & 17 & 83 & 7.8 & 5.47 \\
\hline 3 & $\begin{array}{l}2462.5- \\
2477.5\end{array}$ & 15 & 11 & 0.73 & sand & gas & 11 & 53 & 2.09 & 17 & 29 & 34.5 & 18.9 & 0.25 & 24 & 76 & 9.6 & 6.96 \\
\hline 4 & $2485-2511$ & 26 & 24.5 & 0.94 & sand & gas & 10 & 70 & 2.08 & 18 & 30 & 15 & 22.5 & 0.25 & 20 & 80 & 9.0 & 6.00 \\
\hline 5 & $2590-2617$ & 27 & 18 & 0.67 & sand & gas & 18 & 60 & 2.13 & 22 & 29.8 & 37 & 18.77 & 0.25 & 17 & 83 & 9.1 & 5.07 \\
\hline 6 & $2875-2910$ & 35 & 27.5 & 0.79 & sand & gas & 27.75 & 80 & 2.13 & 18 & 28 & 37 & 17.64 & 0.17 & 16 & 84 & 10.33 & 4.8 \\
\hline 7 & $2921-2964$ & 43 & 38.25 & 0.89 & sand & gas & 38.25 & 63 & 2.22 & 19 & 25 & 36 & 16 & 0.17 & 21 & 79 & 12.96 & 5.25 \\
\hline 8 & $3248-3275$ & 27 & 21 & 0.77 & sand & gas & 21 & 175 & 2.17 & 15 & 26 & 14 & 22.36 & 0.28 & 15 & 85 & 11.98 & 3.98 \\
\hline 9 & $\begin{array}{l}3276- \\
3290.5\end{array}$ & 14 & 10 & 0.71 & sand & gas & 10 & 62 & 2.28 & 14 & 20 & 19 & 16.2 & 0.28 & 30 & 70 & 20.25 & 6.0 \\
\hline 10 & $\begin{array}{l}3292.5- \\
3316.5\end{array}$ & 24 & 22.5 & 0.94 & sand & gas & 22.5 & 210 & 2.20 & 12 & 23 & 16 & 19.32 & 0.28 & 15 & 85 & 15.31 & 3.63 \\
\hline 11 & $3317-3335$ & 18 & 13.25 & 0.75 & sand & gas & 13.25 & 186 & 2.19 & 16 & 24 & 17 & 19.92 & 0.28 & 16 & 84 & 14.1 & 3.84 \\
\hline
\end{tabular}


Table 4. Results of average petrophysical parameters of the four (4) reservoirs of well 2

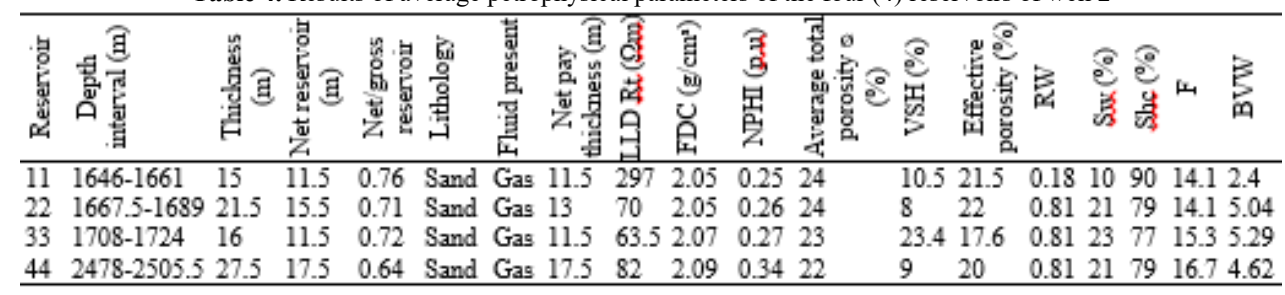

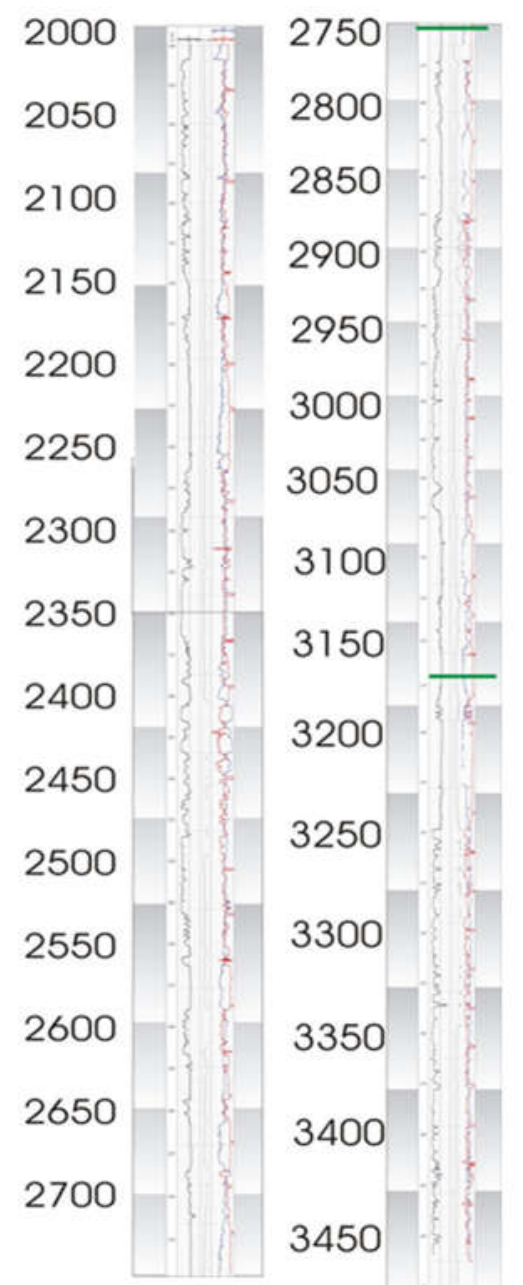

Fig 3: Gamma ray, Neutron Density and Resistivity logs of Well 1

Interpretation: The litho-stratigraphic correlation is a visual process which provides knowledge of the general stratigraphy of an area (Amigun, 1998). Interpretation was carried out on two well logs from wells drilled on the 'Ictorian' field. For the purpose of this study only the hydrocarbon bearing reservoirs were assessed. Sand package intervals were evaluated and the individual reservoirs within these packages were analyzed.

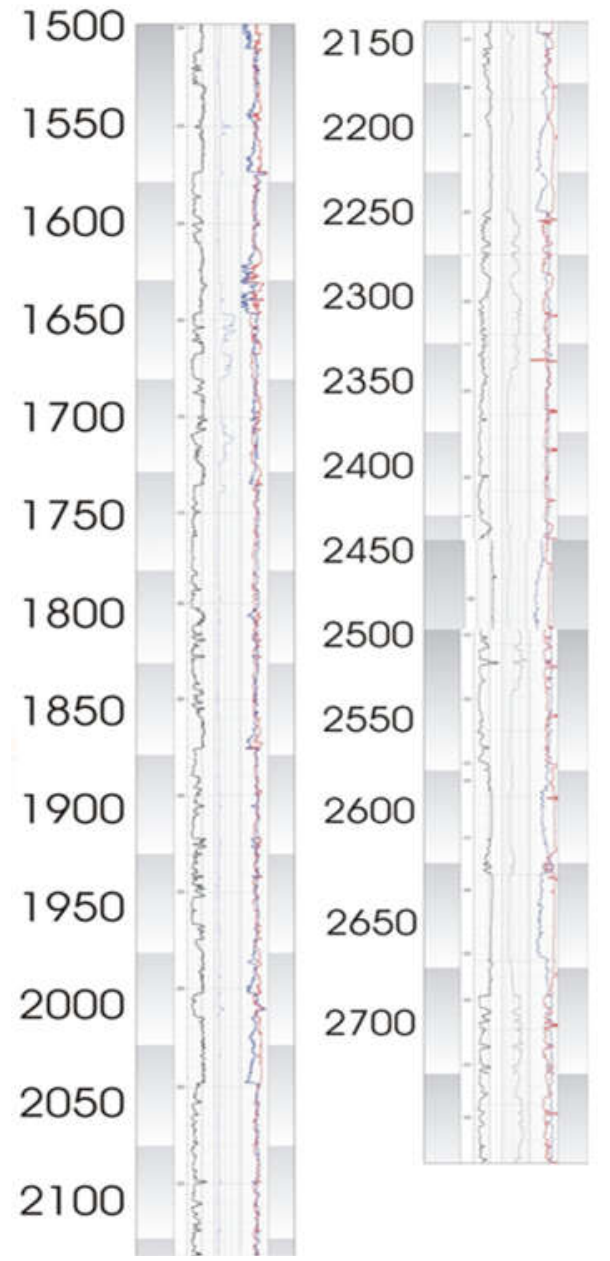

Fig 4: Gamma ray, Neutron Density and Resistivity logs ofWell 2

From this, the Net reservoir was estimated, and then the Net/Gross reservoir estimated. Net reservoir thickness was estimated from the gamma ray logs. The net pay oil and gas thickness was estimated from the resistivity logs and neutron-density logs. The fluid contents were analyzed from the resistivity log. Generally water bearing zones have very low resistivity since they are conductive and the hydrocarbon bearing zone had relatively high resistivities because they are non-conductive. 
Petro-physical Analysis of Well Logs for Reservoir Evaluation.....1004

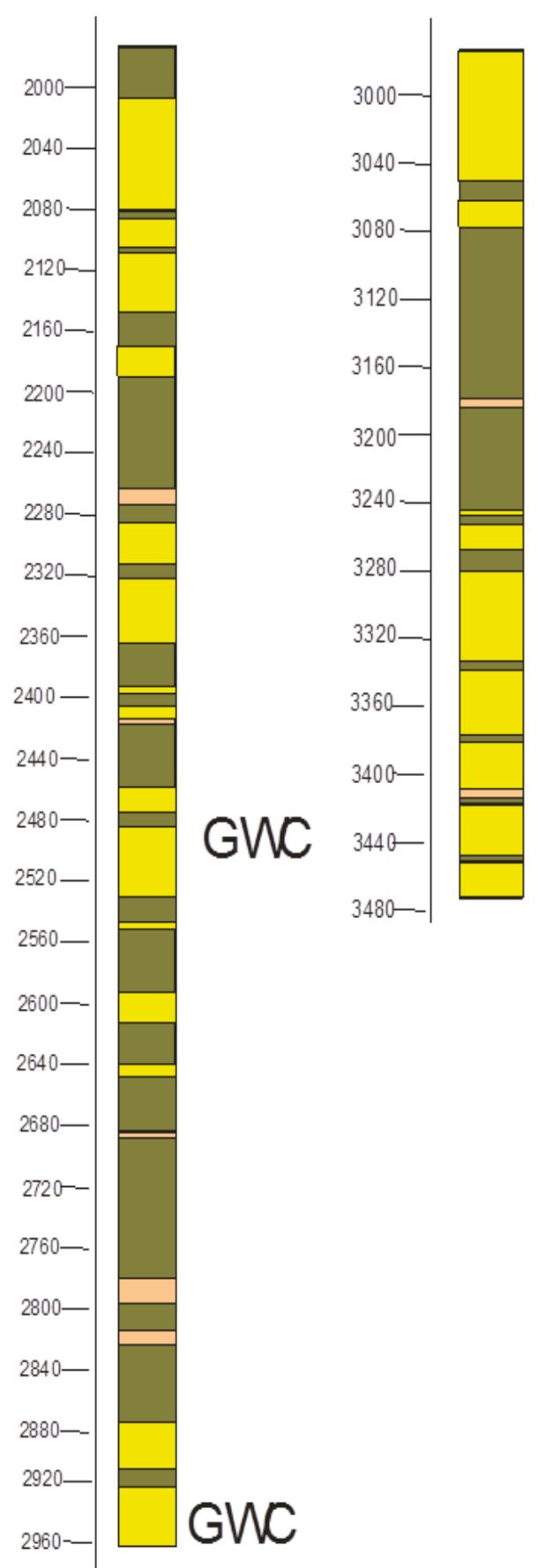

Fig 5: Lithology of well 1

Sand packages intervals were evaluated and the individual reservoirs within these packages were analyzed. From this, the Net reservoir was estimated, and then the Net/Gross reservoir estimated. Net reservoir thickness was estimated from the gamma ray logs. The net pay oil and gas thickness was estimated from the resistivity logs and neutron-density logs.

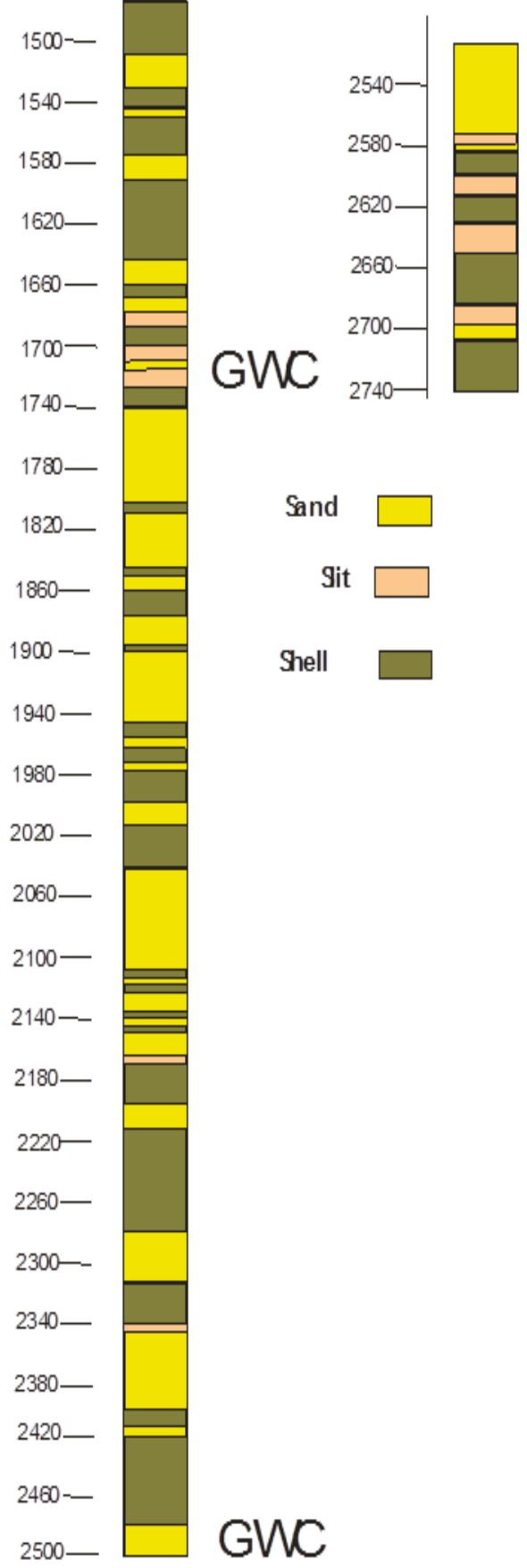

Fig 6: Lithology of well 2

The fluid contents were analyzed from the resistivity $\log$. Generally water bearing zones have very low resistivity since they are conductive and the hydrocarbon bearing zone had relatively high resistivity because they are non-conductive. The hydrocarbon was differentiated into oil and gas using the neutron-density combination log. 


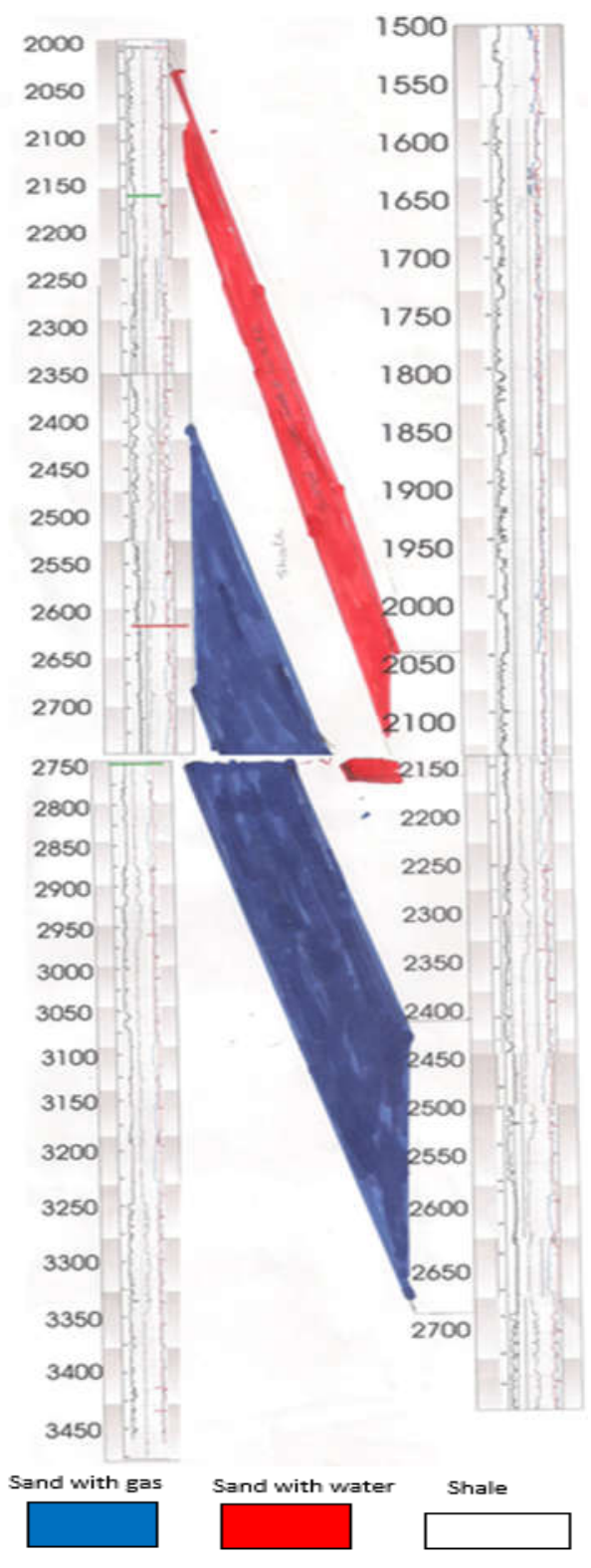

Fig 7: Well Correlation between well 1 and well 2 using Gamma ray, Neutron Density and Resistivity logs of both wells.

The average porosity was estimated from the neutron density cross plot, the effective porosity was further deduced by introducing the shale volume percentage. Effective porosities were estimated and these effective porosities determine the permeability of the reservoirs. The values obtained show that the analysed reservoirs have good permeability. This can be attributed to the friable nature of the Niger delta sands. Water saturation and hydrocarbon saturation was estimated from the formation resistivity values gotten from the resistivity $\log$.
The hydrocarbon was differentiated into oil and gas using the neutron-density combination log. The average porosity was estimated from the neutron density cross plot, the effective porosity was further deduced by introducing the shale volume percentage. Effective porosities were estimated and these effective porosities determine the permeability of the reservoirs. The values obtained show that the analyzed reservoirs have good permeabilities. This can be attributed to the friable nature of the Niger delta sands. Water saturation and hydrocarbon saturation was estimated from the formation resistivity values gotten from the resistivity log. Only the hydrocarbon bearing reservoirs were assessed in this study.

\begin{tabular}{ll}
\multicolumn{2}{c}{ Table 5: Qualitative evaluation of porosities. } \\
\hline Percentage porosity & Qualitative evaluation \\
\hline $0-5$ & Negligible \\
$5-10$ & Poor \\
$15-20$ & Good \\
Over $20-25$ & Very good \\
Over 30 & Excellent \\
\hline
\end{tabular}

For well 1: Eleven (11) reservoirs bearing hydrocarbons (oil and gas) were identified. The volume of shale had values ranging from $36-14 \%$. The volume of shale in each reservoir had a direct effect on the effective porosity and the zones with high volume of shale had a reduced porosity. Effective porosities had values ranging from $26-16 \%$. These effective porosities determine the permeability of the reservoirs, the values obtained show that the analysed reservoirs have good permeability. This can be attributed to the friable nature of the Niger Delta sands. Reservoir 1 -7 and Reservoir 8-11 contained gas. Well 1 had Gas Water contact at $2497 \mathrm{~m}$ and $2964 \mathrm{~m}$. The sands within the pay zones were fairly homogenous. Below the oil bearing reservoirs, the presence of thick shale bed acted as a seal. Below the shale lithology, there was an occurrence of another gas bearing reservoir.

For well 2: Four (4) reservoirs bearing hydrocarbon were identified. All the sands within the pay zones of this well were satisfactorily homogenous. The volume of shale had values ranging from $23-10 \%$. Effective porosities had values ranging from $22-17 \%$. Reservoir 1-4 contained gas all through. Well 2 had Gas Water Contacts at $1739 \mathrm{~m}$ and $2510 \mathrm{~m}$. The analysis of the GR $\log$ shows that the overall lithology is an alternating sequence of sands and shales. The porosity values obtained from the reservoirs varied from those obtained by Edwards and Santogrossi (1990), therefore it is suggested that the reservoirs are different in age as compared to those analysed by Edwards and Santogrossi (1990). The results showed that all the hydrocarbon zones within well 1 and 2 are producible since they all have hydrocarbon saturations greater 
than $65 \%$ and porosity values ranged from good to excellent. The calculated values indicate that porosity, permeability values from the hydrocarbon bearing reservoir are good enough for commercial accumulation in the Niger Delta.

Conclusion: The results showed that all the hydrocarbon zones within well 1 and 2 are producible since they all have hydrocarbon saturations greater than $65 \%$ and porosity values ranged from good to excellent. The calculated values indicate that porosity, permeability values from the hydrocarbon bearing reservoir are good enough for commercial accumulation in the Niger Delta. Borehole pressure data should be in use for accurate determination of fluid contacts. The GWC and GOC were all estimates deduced from the depth intervals of the gamma ray, neutron density and resistivity logs.

Acknowledgement: Acknowledgement: Authors are extremely grateful to Prof. W.O. Emofurieta and Mr.U.O.Diakparomre for their input in this work.

\section{REFERENCES}

Abe, SJ; Olowokere, MT (2013). Reservoir Characterization and Formation Evaluation of Some Parts of Niger Delta using 3-D seismic and well log data research. J. Engr. Appl. Sci., 2(4): 304-307

Amigun, JO (1998). Interpretation of Seismic Reflection Data over Okpoko oil Field, Niger Delta; (unpublished M.Sc thesis) Obafemi Awolowo University, Ile-Ife.
Edwards, JD; Santogrossi, PA (1990). Summary and conclusions, In, J.D Edwards and P.A Santogrossi (eds.), Divergent/passive Margin Basins, AAPG Memoir 48: Tulsa, 239-248.

Ekine, AS; Iyabe, P (2009). Petrophysical characterization of the Kwale field reservoir sands (OML 60) from wire-line logs, Niger Delta, Nigeria. J. Appl. Sci. Environ. Mgt., 13(4): $81-$ 85.

Evamy, BD; Haremboure, J; Kamerling, P; Molloy FA; Rowlands, PH (1978). Hydrocarbon habitat of Tertiary Niger Delta. Am. Assoc. Petrol. Geologists Bull., 62: 1-39.

Microsoft Encarta (2006). Reference Library Premium, DVD-ROM

Ologe, O (2016). Reservoir evaluation of " $T$ - $X$ ” field (Onshore, Niger Delta) from well log petrophysical analysis. Bayero J. Pure \& Appl. Sci., 9(2): $132-140$

Olowokere, MT (2009b). 3D seismic evaluation and opportunity identification in some parts of Niger. The Pacific J. Sci. Technol. 10: 753-762.

Owoyemi, AOD (2004). The Sequence Stratigraphy of Niger Delta, Delta Field, Offshore Nigeria. Unpublished M. Sc. Thesis, Texas A\&M University, $88 \mathrm{p}$.

Weber, KJ; Daukoru, EM (1975). Petroleum geology of the Niger Delta Proceedings of the Ninth World Petroleum. 